DOI: https://doi.org/10.34069/AI/2021.41.05.16

\title{
International experience of public-private partnership in agriculture
}

\section{Міжнародний досвід державно-приватного партнерства у сільському господарстві}

Received: May 5, 2021

Abstract

Agriculture, as one of the most important sectors of the economy, needs constant improvement at the legislative level. Its importance lies in providing the population with provisions and obtaining raw materials for industry. States are trying to create a mechanism for regulating agricultural relations that would be in line with international principles and efficient. One such mechanism is the introduction of the institution of public-private partnership. The experience of foreign countries allows to maintain the state of legislative support at a high level and, accordingly, the effective implementation of its norms at a high level for the implementation of state social policy. The work aims to analyze the international experience of public-private partnerships in agriculture. During the research, the authors used such methods as a method of analysis of normative documents, comparative legal method, and formal-legal method. As a result of the study, the international experience of public-private partnership (in general) and in the field of agriculture (in particular) was examined. The historical stages of formation and improvement of this institute are studied. The advantages and disadvantages of public-private partnership and possible ways to improve it are studied.
Accepted: June 12, 2021
Анотація

Сільське господарство як одна 3 найважливіших галузей економіки країн потребує постійного вдосконалення на законодавчому рівні. Його важливість полягає в забезпеченні населення провізією i отримання сировини для промисловості. Держави намагаються створити такий механізм регулювання сільськогосподарських відносин, який відповідав би міжнародним принципам та був ефективним. Одним 3 таких механізмів $є$ впровадження інституту державно-приватного партнерства. Досвід зарубіжних країн дозволяє підтримувати стан законодавчого забезпечення на високому рівні та відповідно ефективну реалізацію його норм на високому рівні задля реалізації державної соціальної політики. Метою роботи є аналіз міжнародного досвіду державно-приватного партнерства у сільському господарстві. Під час проведеного дослідження ви користувалися так методи, як: історичний, узагальнення, метод аналізу нормативних документів, порівняльноправовий метод, формально-юридичний метод. У результаті проведеного дослідження було проаналізовано міжнародний досвід державноприватного партнерства в цілому та у сфері сільського господарства зокрема. Вивчено

\footnotetext{
${ }^{57}$ Doctor of Legal Science, Professor, Corresponding Member of the National Academy of Legal Sciences of Ukraine. Honored Lawyer of Ukraine, Dean of Law Faculty of Zaporizhzhia National University, Ukraine.

${ }^{58}$ Doctor of Legal Science, Professor, Professor of the Department of Constitutional and Labour Law of Zaporizhzhia National University, Ukraine.

${ }^{59}$ Doctor of Legal Science, Associate Professor, Associate Professor of the Department of Administrative and Business Law of Zaporizhzhia National University, Ukraine.

${ }^{60}$ Ph.D., Associate Professor, Associate Professor of the Department of International Law and Comparative Law of International Humanitarian University, Ukraine.

${ }^{61}$ Ph.D., Associate Professor of the Department of Civil Law of Yaroslav Mudryi National Law University, Ukraine.
} 


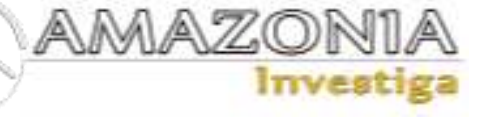

Keywords: public-private partnership, public and private partner, agriculture, international experience.

історичні етапи становлення та вдосконалення даного інституту. Досліджено переваги та недоліки державно-приватного партнерства та можливі шляхи його вдосконалення.

Ключові слова: державно-приватне партнерство, державний та приватний партнер, сільське господарство, міжнародний досвід.

\section{Introduction}

In modern conditions of economic development, states try to maintain it at a high level. The social orientation of democratic countries to create their functions forces them to create and implement effective measures. One such measure is a public-private partnership.

The interaction between the state and the private sector has become a driving force for the modernization of infrastructure in many countries in recent years. Such cooperation makes it possible to increase the level of investment attractiveness in certain regions, reduce risks during the implementation of infrastructure projects, and improve the level of quality of infrastructure services (Nagornyi, 2017).

Public-private partnership is a new phenomenon for Ukraine, but most countries around the world have been using this tool for a long time and proving its effectiveness. The mechanism of public-private partnership proved to be effective, given the combination of partners' resources, risk-sharing, and profit from project implementation.

Public-private partnership as a form of interaction between the state and the private sector for the implementation of socially significant projects appeared in the Middle Ages. Gradually improving it, the states came to legislate the rules governing relations arising in the process of public-private partnership.

In the territory of Ukraine, there is a low level of implementation of public-private partnership projects due to a lack of experience and specialists in the field of public-private partnerships. However, some progress in the use of the public-private partnership mechanism in Ukraine can be seen in the concession, which is a form of its implementation. Thus, Ukraine received 3.7 billion hryvnias of investments. Thanks to changes in the legislation on publicprivate partnerships and state support for investment projects, Ukraine has received tools to attract large investors, who are willing to

invest more than 20 million euros in Ukrainian enterprises (Agropolit, 2020).

Given the above, it is necessary to examine the international experience of public-private partnership in the field of agriculture, to draw attention to the strengths and weaknesses of this issue, and to suggest tools that can drive progressive change in the field.

\section{Theoretical Framework or Literature Review}

The following researchers studied the issue of public-private partnership, both in Ukraine and abroad: Varnavsky (2006), Lazar (2013), Pavlyuk, S., \& Pavlyuk, K. (2010), Matyavina (2008), Vikhryan (2003), Oliynyk (2005), Kazakov (2008), Makarov (2009), Zakharina, Symonenko, \& Saykevych (2018), Knir (2018), Kovaleva (2019), Baranenko (2011), Mygas (2017), and Nagornyi (2017), Pavlova, Polunina, Tkalych, Mankovskyi, \& Zubair (2020).

Varnavsky (2006), Lazar (2013), Pavlyuk S., \& Pavlyuk, K. (2010), and Makarov (2009), in their research, in terms of socio-economic problems, highlighted the concept of public-private partnership, its essence, and role in the development of the state. Thus, Pavlyuk S. and Pavlyuk M. believe that in a broad sense, the interpretation of the concept of public-private partnership includes constructive interaction of the state, private sector, civic institutions in economic, political, social, humanitarian, and other spheres of public activity.

Varnavsky (2006) and Lazar (2013) believe that the interaction of the state and the private sector is an institutional and organizational alliance between public authorities and businesses for the implementation of socially significant projects. Additionally, it should be highlighted, that Kazakov (2008) draws attention to the complexity of defining public-private partnership since it includes many social relations. Furthermore, Makarov (2009) refers to public-private partnerships as the third sector of the economy. 
The historical development of public-private partnerships was studied by Vikhryan (2003) and Oliynyk (2005). In their works, the genesis of public-private partnership from medieval times to the end of the XX century was analyzed.

The international experience of cooperation between the state and the private sector was studied by Knir (2018), kovaleva (2019), and Mygas (2017).

Therefore, Knir (2018) devoted her work to current issues of public-private partnership as a necessary tool for implementing social projects. The study considers the essence of the category of public-private partnership, reveals the features of its most common forms, in particular in the economy of Ukraine, which takes into account economic and political components, which form the process of formation and development of public-private partnership in the world and Ukraine.

What is more, it is worth mentioning, that Kovaleva (2019) considers the general characteristics of the model of public-private partnership in Canada. The general emphasis is on the bodies that ensure the effective operation and development of the public-private partnership program in Canada. The paper also identifies key success factors for Canada's public-private partnership.

Furthermore, Mygas (2017) studied the development of public-private partnerships in Great Britain. In particular, the author drew attention to the theoretical concepts of publicprivate partnership in the world, explored the history of relations between the state and the private sector, the forms of public-private partnership in the UK.

Finally, theoretical and practical aspects of public-private partnership in the world and Ukraine were studied by the following scientists: Nagornyi (2017), Zakharina, Symomenko, \& Saykevych (2018). Their works highlight the basic concepts of public-private partnership, highlight the main benefits that partners receive in the implementation of public-private partnership projects, analyze the relevant risk allocation.

Despite the large number of scientific papers that examine the issue of public-private partnership, such issues as the organizational structure of the institute of the public-private partnership remain unexplored; the possibility of creating a specialized body or organization that would have the authority to coordinate and monitor the implementation of public-private partnership projects; liability for violation of the terms of the public-private partnership agreement; international cooperation in the field of publicprivate partnership, etc.

\section{Methodology}

The methodology determines what and how is studied using a theory that creates a system of elements, where the defining element is subordinate to all others that explain the origin, relationships, nature, and pattern of development of the object of study.

To reveal the research topic, the following methods were used: historical, generalization, method of analysis of normative documents, comparative legal method, formal-legal method, method of observation, and abstraction.

First of all, we should pay attention to the interest of using the historical method. The historical method was used in the study of the historical stages of development of the institution of public-private partnership, traced the patterns of its improvement in different countries.

The method of generalization helped to highlight the provisions on the essence of public-private partnership, the relations arising from it, to highlight the advantages and disadvantages of its use in practice. Also, by summarizing the international experience - public-private partnerships in agriculture, conclusions were drawn on the improvement of public-private partnerships in Ukraine.

Theoretical aspects of public-private partnership in Ukraine were studied by analyzing normative documents, in particular, the Law of Ukraine "On Public-Private Partnership" (Law No. 2404-VI, 2010) helped to highlight the general provisions of the mechanism of interaction between the state and the private sector for the implementation of socially significant projects, the procedure for its application, the choice of a private partner, etc.

Naturally, a special role in the study of this topic should be given to the comparative-legal method, which allowed to compare different models of public-private partnership, mechanisms for its provision.

It should be remarked, that with the help of the formal-legal method, the concept of publicprivate partnership is defined, the need to 


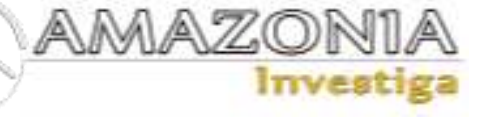

improve the legislation in the field of publicprivate partnership is substantiated.

Observation is a purposeful study of objects, which is mainly based on the data of the senses (sensations, perceptions, ideas). It was with his help that it became possible to formulate conclusions about the transfer of international experience of public-private partnership to the domestic level and identify its main advantages.

Additionally, the method of abstraction (which consists in the mental distraction from a number of properties and relations of the phenomenon under research, while highlighting the properties (primarily essential, general) of interest in a particular study) was useful in studying the general theoretical characteristics of publicprivate partnership on the example of foreign countries and, on this basis, the existing practice of public-private partnership in the field of agriculture is studied.

Using such a method as an experiment, ways to improve the institution of a public-private partnership at the national level were proposed, referring to international experience. Also by interpreting as one of the elements of this method the doctrinal concepts of public-private partnership, the mechanisms of its implementation were studied.

Finally, the system method during the research allowed to consistently create a presentation of the material as a whole, to structure examples of public-private partnership projects that have been implemented in foreign countries.

\section{Results and Discussion}

\section{Public-private partnership: international experience in the agricultura}

In current conditions, public-private partnership has been beneficial for successful socioeconomic development at the regional and state levels.

The developed countries of the world do not lose the opportunity to use an effective tool to achieve successful results in ensuring the social wellbeing of their citizens.

Knir (2018) divides the states into three groups according to the level of development of the public-private partnership. Thus, the first (highest) group of development includes Great Britain and Australia; the second (middle) - e.g. the United States, Japan; the third (lowest) - e.g. Slovakia, India, Latvia, Czech Republic, Russia. Ukraine also belongs to the latter.

Among the many areas of economic activity, agriculture plays an essential role in providing the population with food, obtaining raw materials for a number of industries, the application of state export policy.

Examples of public-private partnerships in agriculture in foreign countries can be seen in Table 1.

Table 1.

Public-private partnerships in agriculture in foreign countries. Data provided by Zakharina, Symomenko, \& Saykevych (2018).

\begin{tabular}{ll}
\hline Scope of public-private partnership & Countries \\
\hline $\begin{array}{l}\text { Construction, operation and management of irrigation } \\
\text { projects }\end{array}$ & India, Peru, Morocco, Jordan, Brazil \\
$\begin{array}{l}\text { Construction, maintenance and management of markets } \\
\text { for the construction of fruits, vegetables and local }\end{array}$ & Philippines, Jordan \\
agricultural products & \\
$\begin{array}{l}\text { Processing of agricultural waste } \\
\text { Squeezing sugar cane to generate electricity }\end{array}$ & Moldova \\
\hline
\end{tabular}

Ethiopia is a clear example of a public-private partnership to ensure the functioning of irrigation systems.

In 2006, the Ethiopian government, with the support of the World Bank, prepared an Irrigation Action Plan using a public-private partnership mechanism. This land irrigation strategy helps to attract investment, restore irrigation and increase crop yields in general, which, in turn, contributes to the development of the country's economy.

The Ethiopia Public-Private Partnership for Irrigation Systems provided:

1. Preparation of tender documents and draft agreement on irrigation systems. 
2. Signing of an agreement on the involvement of the French operator BRL Ingénierie for the operation and maintenance of the project.

3. Obtaining construction funding from the Ethiopian government.

4. Planning to increase the level of water supply for more than 6 thousand land holdings and cover maintenance costs.

A similar public-private partnership project exists in Brazil. According to him, the government has committed to allocate land and the necessary infrastructure, the private partner is responsible for the development of infrastructure to ensure full irrigation of the site, undertakes to transfer at least $25 \%$ of the land provided to farmers. Similarly, under the project, the private partner makes a profit by selling water and paying for capacity from the government (White, 2013).

In the Philippines, an example of a public-private partnership is a cold storage system agreement that involves a large number of customers, manufacturers, and distribution companies that can maintain a certain temperature range to ensure the storage of perishable products (natural agricultural products, seafood, frozen products, chemical and pharmaceutical products, etc.).

In addition to agriculture, public-private partnership agreements are successful in other sectors of the economy. Most public-private partnership projects in the EU were in the following areas (The Ministry of regional development, construction, housing and communal services, 2017):

- $\quad$ transport $31 \%$;

- medicine 19\%;

- education $13 \%$;

- telecommunications $10 \%$.

The above statistics indicate the prospects for the development of the public-private partnership market in Ukraine.

Attention should also be paid to the publicprivate partnership model in Canada.

Unlike a number of other countries, Canada has established the Public-Private Partnership Development Council of Canada (PPP Canada), which is a national, non-profit, collective organization with a wide range of representatives from both the public and private sectors. Its activities are aimed at promoting the idea of public-private partnership through research, scientific conferences, etc. The most important feature of the Canadian Public-Private Partnership Institute is the state's funding of draft agreements concluded on a public-private partnership basis and the consultation of private partners by PPP Canada specialists (Kovaleva, 2019).

Regarding the system of cooperation between the state and the private sector in the United States, we can distinguish the following features:

- the absence of a federal law that would establish common approaches to the implementation of public-private partnership projects;

- an organization responsible for the development of public-private partnerships in the United States - the National Council for Public-Private Partnerships (The National Council for Public-Private Partnerships). It promotes the introduction of a public-private partnership at all levels of government and creates conditions for cooperation between the public and private sectors in socially important areas (Baranenko, 2011).

The board has the following functions:

1) informative - the organization provides general information to promote publicprivate partnership, is responsible for information exchange between the state and the private sector in the practical implementation of public-private partnership;

2) educational - the creation of training, seminars on public-private partnership;

3) auxiliary - the council provides methodological support during the preparation and implementation of publicprivate partnership projects, analyzes the regulatory framework governing publicprivate partnerships;

A large share of involvement of commercial firms to perform certain activities of municipal authorities (water supply, sewerage, garbage collection, school education, etc.). So from 65 basic kinds of activity of the municipal power in each settlement commercial firms are involved on the average for the performance of 23 , which allows the local power to save from 20 to 50 percent of budgetary funds (Mygas, 2017).

Thus, given the above, it is possible to conclude about the effectiveness of the institution of public-private partnership for the state economy, 


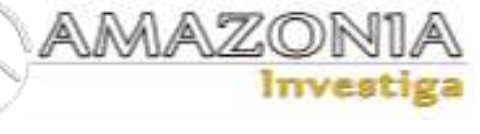

which follows from the delegation of socially significant powers of the state to private partners, which is fixed in the contract. In addition, publicprivate partnerships are an effective tool in providing society with vital resources, such as road construction and repair, supply and storage of food for the population, assistance in agriculture (irrigation and drainage of land, etc.).

The example of Ethiopia, Brazil, and the Philippines shows effective work related to the implementation of public-private partnership projects in agriculture. The experience of Canada and the United States also creates prospects for the implementation of public-private partnership projects, as in these countries there is a PPP system, which is constantly improved by creating specialized bodies for public-private partnership and and holding qualified meetings on the development of public-private partnership as an institution in general and training in particular.

\section{Public-private partnership as a mechanism for implementing public policy and interaction between the state and business}

The partnership between the state and the private sector began long before the formation of modern legal systems. The first mention of such cooperation can be seen in the form of a concession dating from the XII-XIII centuries. Thanks to agreements between the state and entrepreneurs, cities were built, and new lands were arranged in France.

During the XVI-XVIII centuries, French monarchs gave permission for the construction of roads, bridges, canals, dams, street lighting, garbage collection, mail delivery, public transport, opera houses to entrepreneurs (Vihryan, 2003).

A similar system of cooperation also existed in the United Kingdom. In the second half of the XVIII century, a concession agreement was signed for the construction of the Oxford Canal (USAID, 2011).

Agreements in the framework of public-private partnership in their modern sense began to be concluded in the early XIX century. in European countries mainly in the field of urban and communal services, construction of railways and highways, etc.

In the United States, public-private partnerships date back to the 1950s. Thus, the first publicprivate partnership projects were aimed at financing educational programs and urban development (Matyavina, 2008).

On the territory of Ukraine, the embryos of public-private partnership appeared in the second half of the XIX - early XX centuries. Thus, during this period, based on the concession agreement, a centralized water supply system was built, city lighting was installed, and public transport was launched. In 1871, the Gas Lighting Society was registered, with which the City Duma signed a contract for the installation of street gas lanterns (Oliynyk, 2005).

With the development of states and their legislation, the concept of concession and the relations arising from it have been somewhat separated and detailed. Ukraine is no exception. It should be noted that the division of law into private and public is a scientific abstraction, which allows to characterize in general terms the two main areas of legal regulation of public relations (Kharytonov, Kharytonova, Kolodin, \& Tkalych, 2020).

Following paragraph 11 of Part 1 of Art. 1 of the Law of Ukraine "On Concession" (Law No. 155IX, 2019) concession is a form of public-private partnership, which provides the concessionaire to the concessionaire the right to create and / or construction (new construction, reconstruction, restoration, overhaul and technical reequipment), and / or management (use, operation, and maintenance) of the concession object, and / or provision of socially significant services in the manner and under the conditions specified in the concession agreement, and also provides for the transfer to the concessionaire of most of the operational risk, including demand risk and / or supply risk. In addition, this document details the procedures for initiating and deciding on a public-private partnership, including concessions, the concession tender procedure, the selection of a concessionaire (private partner), and many other relevant provisions.

On July 1, 2010, the Law "On Public-Private Partnership" (Law No. 2404-VI, 2010) was adopted, which defines the organizational and legal principles of interaction of public partners with private partners and the basic principles of public-private partnership on a contractual basis. Following Part 1 of Art. 1 of this Law, publicprivate partnership - cooperation between the state of Ukraine, territorial communities represented by the relevant state bodies that, under the Law of Ukraine "On Management of State Property" manage state property, local 
governments, the National Academy of Sciences of Ukraine, national branch academies of sciences (state partners) and legal entities, except for state and communal enterprises, institutions, organizations (private partners), which is carried out based on an agreement in the manner prescribed by this Law and other legislative acts and meets the characteristics of public-private partnership, defined by this Law. The main principles of public-private partnership in Ukraine in Article 3 of the Law.

Besides, the Law also contains norms on the forms of implementation and objects of publicprivate partnership, on the procedure for making a decision on the application of public-private partnership, on the definition of a private partner, on state support, guarantees, and control.

There is no consensus among scholars on the definition of public-private partnership. Thus, Lazar and Varnavsky define the interaction of the state and the private sector as an institutional and organizational alliance for the implementation of national and international, large-scale, socially significant projects in a wide range - from the development of strategically important industries to public services (Varnavsky, 2006; Lazar, 2013). According to Pavlyuk, \& Pavlyuk, (2010), public-private partnership is the cooperation of the state, private sector, civic institutions in political, economic, humanitarian, and other spheres of public activity to implement socially significant projects based on the priority of state interests, its political support, consolidation of resources of the parties, effective distribution of risks between them, equality and transparency of relations. Makarov believes that by combining elements of the private and public sectors of the economy, the public-private partnership can be considered a third sector of the economy.

Thus, we can conclude that public-private partnership is a rather broad concept and covers various forms of cooperation between the public and private sectors. And the first is the customer of certain works, and the second - their executor. As noted by Kazakov (2008), one of the problems that arise during the intention to define public-private partnership is a fairly wide range of relations that could potentially fall under the scope of public-private partnership.

The multifaceted study of the public-private issue and the attention to it testify to its great potential. However, as practice shows, in Ukraine, the use of the mechanism of publicprivate partnership is at a fairly low level.
According to the statistics of central and local executive bodies in Ukraine as of 2021 on the terms of PPP concluded 192 agreements, of which 39 agreements are completed (29 concession agreements, 6 - agreements on joint activities, 4 - other agreements), 153 - not performed (118 - not implemented, 35 terminated / expired) (Ministry of Economic Development and Trade of Ukraine, 2021).

Despite the "unpopularity" of public-private partnership in Ukraine, it is possible to determine its advantages, namely:

- providing the government with access to alternative private sources of capital;

- use by the state of financial, organizational, intellectual capabilities of a private partner to meet socially significant needs;

- optimal distribution of risks;

- the use of management technologies of the private sector

- improving the quality of services provided as a result of combining the resources of the private and public sectors.

However, the implementation of projects on the terms of public-private partnership has the following disadvantages:

- creation of financial liabilities for the long term;

- given the lack of sufficient experience in the implementation of projects on a publicprivate partnership, the lack of necessary high-level specialists;

- due to the length of the concluded agreements, it is impossible to take into account all possible risks that may arise during the implementation of the planned project.

Thus, given the above, we can conclude that the institution of public-private partnership in Ukraine at an early stage of development. Given the identified advantages and disadvantages, the need for further development of public-private relations requires borrowing international experience.

\section{Conclusions}

As a result of the study, the following conclusions were made.

1. Public-private partnership in the field of agriculture has advantages and disadvantages. The benefits are that the government has access to alternative private 


\section{AMAZONDA}

sources of capital, the state can use the financial, organizational, intellectual capabilities of the private partner to meet socially urgent needs, and the use of private sector management technologies allows more effective implementation of a number of public sector activities. However, the administration of projects in a public-private partnership has such disadvantages as the creation of financial obligations in the long run and the inability to take into account all possible risks that may arise during the implementation of the planned project.

2. Different models of public-private partnership in the field of agriculture are singled out. For example, in Canada, the Public-Private Partnership Council of Canada (PPP Canada) has been established, which is a national, non-profit collective organization with a wide range of representatives of both the public and private sectors, and the United States has established a development organization. Public-Private Partnership in the United States - National Council for Public-Private Partnership.

3. Different countries have implemented models of public-private partnership in different ways (from the implementation of individual laws to the usual conclusion of agreements).

Given Ukraine's international experience, it is considered necessary to integrate positive provisions to increase the share of public funding of public-private partnership projects, initiate and develop a number of effective legislative changes, including the creation of a separate body to deal exclusively with public-private partnership.

\section{Bibliographic references}

Agropolit (2020). Ukraine received 3.7 billion in investments from the concession. Recovered from https://agropolit.com/news/19156ukrayina-otrimala-37-mlrd-grn-investitsiy-vidkontsesiyi

Baranenko, I.O. (2011). The role of publicprivate partnership in ensuring the sustainable development of the state. Modern regional policy: education, science, practice, 2, 6-8.

Kazakov, A.A. (2008). Public-private partnership: conceptual framework. Problems in Russian legislation, 2, 413-415.

Kharytonov, E., Kharytonova, O., Kolodin, D., \& Tkalych, M. (2020). The Covid-19 Pandemic and the Rights of the Individual in Terms of Private and Public Law. Ius Humani. Law Journal, 9(2),
225-250. Recovered from https://doi.org/10.31207/ih.v9i2.253

Knir, M.O. (2018). Public-private partnership: world experience and experience of Ukraine. Scientific notes of the National University "Ostroh Academy". Series "Economics, 10 (38), 10-14. Recovered from https://journals.oa.edu.ua/Economy/article/down load/2005/1802/3598

Kovaleva, E.I. (2019). Canadian model of public-private partnership. General characteristics and application experience. New legal bulletin, 3(10), 15-19. Recovered from https://moluch.ru/th/9/archive/125/4185/

Law No. 155-IX, On the concession. Bulletin of the Verkhovna Rada of Ukraine, Kyiv, Ukraine, October 3, 2019. Recovered from https://zakon.rada.gov.ua/laws/show/155-

20\#Text

Law No. 2404-VI, On public-private partnership. Bulletin of the Verkhovna Rada of Ukraine, Kyiv, Ukraine, July 1, 2010. Recovered from https://zakon.rada.gov.ua/laws/show/2404-

17\#Text

Lazar, Y. (2013). Investment mechanism of social responsibility development on the basis of public-private partnership. Socio-economic problems and the state, 2(9), 75-88. Recovered from

http://sepd.tntu.edu.ua/images/stories/pdf/2013/ 13lyvdpp.pdf.

Makarov, I.M. (2009). Public-private partnership today and the modern economy: regulation and partnership. Russian entrepreneurship, 8(2), 22-28

Matyavina, M.V. (2008). Public-private partnership: foreign experience and opportunities for its use in Russia (doctoral thesis). Financial Academy under the Government of the Russian Federation, Moscow. Recovered from https://www.dissercat.com/content/gosudarstven no-chastnoe-partnerstvo-zarubezhnyi-opyt-ivozmozhnosti-ego-ispolzovaniya-v-ross/read Ministry of Economic Development and Trade of Ukraine. (2021). Status of implementation of public-private partnership in Ukraine. Recovered from

https://www.me.gov.ua/Documents/Detail?lang $=$ uk-UA\&id=9fc90c5e-2f7b-44b2-8bf1-

$1 \mathrm{ffb} 7$ ee 1 be $26 \&$ title=StanZdiisnenniaDppVUkra ini

Mygas, I.I. (2017). Public-Private Partnerships in United Kingdom and its New Forms (doctoral thesis). Educational and Scientific Institute of International Economic Relations named after B.D. Gavrilishin, Ternopil. Recovered from http://dspace.wunu.edu.ua/bitstream/316497/23 136/1/\%d0\%9c\%d0\%b8\%d0\%b3\%d0\%b0\%d1 $\% 81 \% 20 \% \mathrm{~d} 0 \% 86 . \% \mathrm{~d} 0 \% 86 . . \mathrm{pdf}$ 
Nagornyi, E.O. (2017). Public-private partnership as a mechanism of investment interaction between the state and business in Ukraine. Black Sea Economic Studies, 23, 186-190. Recovered from https://ir.kneu.edu.ua/bitstream/handle/2010/329 89/bses_2017_23_37.pdf?sequence=1\&isAllow ed $=\mathrm{y}$

Oliynyk, V. (2005). A man who "built an eternal monument to himself", but was safely forgotten by the people of Kiev: On the engineer Amand Egorovich Struve (1835-1898). Mirror of the week, 20, 2-3.

Pavlova, Y., Polunina, O., Tkalych, M., Mankovskyi, V., \& Zubair, A. (2020). International-legal standards of cooperation of Ukraine in the field of environmental (climate) problems. Amazonia Investiga, 9(25), 295-301. https://amazoniainvestiga.info/index.php/amazo nia/article/view/1069

Pavlyuk, K., \& Pavlyuk, S. (2010). The essence and role of public-private partnership in the socio-economic development of the state. Scientific works of Kirovograd National Technical University. Economic sciences, 17, 10-19. Recovered from http://nbuv.gov.ua/UJRN/Npkntu_e_2010_17_4 The Ministry of regional development, construction, housing and communal services. (2017). Public-private partnership as a mechanism for implementing a new regional policy: applications and practical aspects of preparation and implementation of investment projects. Kyiv: The Ministry of regional development, construction, housing and communal services. Recovered from http://rdpa.regionet.org.ua/images/129/PPP_rep ort_U-LEAD_30_10_2017.pdf

USAID. (2011). Preparation and implementation of public-private partnership projects: practical manual for local authorities and business. Kyiv: Moskalenko. Recovered from https://enefcities.org.ua/upload/files/Publication s/PPP_report_USAID_2011_ua.pdf Varnavsky, V.G. (2006). State and business. Moscow: IMEMO RAS.

Vikhryan, A.P. (2003). Concession (historical excursion). Bulletin of the Ministry of Property of Russia, 1, 66-72.

White, N. (2013). Public-private partnership in agriculture: international experience and prospects in Ukraine. Kyiv: USAID. Recovered from http://ppp-ukraine.org/wpcontent/uploads/2014/01/Edward-White-PPPsin-Agriculture-for-Ukraine-UKR-1.pdf

Zakharina, O., Symomenko, L., \& Saykevych, M. (2018). Public-private partnership as a mechanism for developing the infrastructure of the region. Public administration: improvement and development, 2, 3-4. Recovered from http://www.dy.nayka.com.ua/pdf/2_2018/32.pdf 